\title{
APLIKASI DIAGNOSA KERUSAKAN MOTOR 4 TAK HONDA VARIO DENGAN ALGORITMA C4.5
}

\author{
Baktiar Setiyaji ${ }^{1)}$; Teguh Susyanto ${ }^{2)}$; Dwi Remawati ${ }^{3)}$ \\ ${ }^{1,2)}$ Program Studi Sistem Informasi, STMIK Sinar Nusantara Surakarta \\ 3) Program Studi Teknik Informatika, STMIK Sinar Nusantara Surakarta \\ 1)baktiar93@gmail.com, ${ }^{2)}$ teguh@sinus.ac.id, ${ }^{3)}$ dwirema@sinus.ac.id
}

\begin{abstract}
Users of motorcycle vehicles more and more, it is necessary a system that can help motorcycle users to solve the problem of damage that occurred on the motorcycle especially Honda Vario in 2006 -2013. The system is knowledge-based to identify motorcycle damage that is displayed using a web-based programming language. The research method for this expert system using algorithm C4.5. Algorithm C4.5 is to form decision tree and used to classify damage become damage which most influence motor to light damage. The resulting output is the creation of a system that can help the user for the initial handling that occurs on a motorcycle and is expected to accelerate the repair of a motorcycle classified as minor damage.

Keywords: Diagnose the Damage, Algorithm C4.5, Expert System, Motorcycle
\end{abstract}

\section{PENDAHULUAN}

Saat ini kebutuhan transportasi sudah menjadi kebutuhan yang mendasar. Salah satunya penggunaan motor matic dari berbagai jenis dan produsen. Pada umumnya pengguna motor kurang mengerti tentang kerusakan yang terjadi pada sepeda motornya dan cenderung menyerahkan kepada mekanik tanpa mengetahui apakah kerusakan sederhana atau rumit untuk diperbaiki. Dengan pertimbangan tersebut maka perlu dibuatlah sistem alat bantu untuk mendeteksi kerusakan yang terjadi pada sepeda motor Honda Vario khususnya produksi tahun 2006 - 2013. Dalam pembuatan sistem ini menggunakan algoritma C4.5 sebagai pembentuk pohon keputusan dan pembentukan rule yang nantinya akan digunakan pada system [1].

Tujuan dalam paper ini adalah untuk menciptakan aplikasi untuk mendiagnosa kerusakan motor 4 tak jenis Honda vario dengan menggunakan metode C4.5. Aplikasi ini diharapkan mampu mendeteksi setiap kerusakan-kerusakan yang mungkin terjadi pada jenis motor Honda Vario berdasar gejalagejala yang dialami.

\section{TINJAUAN PUSTAKA}

Penelitian sistem diagnosa kerusakan motor telah banyak diusulkan, di antaranya [2], [3], [4], [5], [6], [7] dan [8]. Sedangkan penelitian yang terkait dengan system pendeteksi selain kendaraan roda dua pernah diusulkan oleh Ariwibowo dan Khomsah [9] terkait dengan deteksi kerusakan barang elektronik, dan Kurniawan and Merlina [10] telah mengusulkan sistem pendeteksi kerusakan pada mobil Ayla.

Terkait dengan usulan-usulan penelitian di atas sebagian besar aplikasi sistem pendeteksi kerusakan diimplementasikan dalam wujud aplikasi sistem pakar [11], di mana metode Forward Chaining paling umum diterapkan.

Metode Forward Chaining dimanfaatkan pada penelitian [2],[4], [5], [7], [8], [9] dan [10]. Metode ini digunakan untuk mengimplementasikan mesin inferensi dalam mendeteksi setiap gejala-gejala yang diinputkan.

Pada penelitian [3] mengusulkan aplikasi diagnosa kerusakan motor dengan menggunakan pendekatan Case Base Reasoning dengan metode Nearest Neighbour.

Hasil pengujian aplikasi diagnosa kerusakan motor pada [3] memperlihatkan aplikasi yang diusulkan memiliki kemampuan mendiagnosa kerusakan dan memberikan solusi penyelesaian masalah dari pengguna dengan rata-rata nilai similaritas antara 0,62 dan 0,7 dengan nilai keakuratan solusi dari pakar sebesar $80 \%$ dan $90 \%$.

Pada penelitian ini, lebih difokuskan pada pembuatan pohon keputusan untuk mengelola gejala-gejala dan alternatif kemungkinan kerusakan sebagai basis pengetahuan. Cara seperti ini memungkinkan setiap gejala yang dikelola akan dipilah dari yang paling umum menuju ke gejala yang 
paling khusus. Hal ini penting dilakukan karena setiap kerusakan motor yang terjadi dapat difokuskan pada gejala-gejala yang memiliki keterkaitan secara langsung.

\section{METODE PENELITIAN}

\subsection{Metode Pengumpulan Data}

Data merupakan faktor penting dalam penelitian, untuk itu diperlukan teknik tertentu dalam pengumpulan data. Metode pengumpulan data yang penulis gunakan dalam penelitian ini sebagai berikut :

\section{a. Observasi}

Pengumpulan data dilakukan dengan melakukan pengamatan dan pencatatan datadata terkait proses deteksi kerusakan motor vario pada lokasi bengkel yang di survei.

b. Wawancara

Tahap wawancara digunakan untuk memperoleh data dengan mengajukan pertanyaan-pertanyaan secara langsung kepada seorang pakar. Untuk tahap wawancara ini narasumber yang bersangkutan adalah seorang pengajar di SMK N 2 WONOGIRI. Usaha untuk mengumpulkan data dengan mengajukan sejumlah pertanyaan yang berkaitan dengan penelitian. Cara ini untuk mendapatkan keterangan-keterangan pelengkap guna kelancaran kegiatan penelitian pada bidang yang akan diteliti, khususnya bidang kerusakan pada motor vario 4 tak.

c. Studi Pustaka

Studi Pustaka dilaksanakan mengumpulkan data-data yang berkaitan gejala-gejala, kerusakan motor vario pada buku-buku referensi. Selain itu dikumpulkan juga data-data pengetahuan berkaitan dengan solusi sebagai langkah perbaikan dari kerusakan sepeda motor vario.

3.2. Metode Analisa dan Perancangan Sistem

a. Analisa Sistem

1. Analisa Sistem yang Berjalan

Analisa sistem yang berjalan digunakan untuk mengetahuai cara kerja sistem yang sedang berjalan saat ini.

2. Analisa Sistem yang diusulkan

Analisa sistem yang diusulkan digunakan untuk mengetahui kebutuhan sistem yang nantinya akan dibuat.

b. Perancangan Sistem

1. Hierarchy Input Output (HIPO)

Hierarchy Input Output (HIPO) digunakan untuk mempersiapkan penggambaran Diagram Arus Data untuk menuju level-level lebih bawah lagi. Bagan berjenjang dapat digambarkan dengan menggunakan notasi poses yang digunakan di Diagram Arus Data.

2. Konteks Diagram

Konteks Diagram merupakan pola penggambaran yang berfungsi untuk memperlihatkan interaksi sistem informasi tersebut dengan lingkungan dimana sistem tersebut ditempatkan.

\section{Data Flow Diagram (DFD)}

Data Flow Diagram (DFD) merupakan peralatan yang berfungsi untuk menggambarkan secara rinci mengenai sistem sebagai jaringan kerja antar fungsi yang berhubungan satu sama lain dengan menunjukkan dari dan kemana data mengalir serta penyimpanannya.

c. Alat dan bahan

Alat yang digunakan dalam pembuatan sistem ini terdiri dari 2 macam, yaitu Hardware dan Software.

\section{Hardware (Perangkat Keras)}

Perangkat keras yang digunakan dalam pembuatan aplikasi ini adalah sebagai berikut :

- Intel(R) Pentium(R) CPU N3700 @ 1.60GHz (4 CPUs)

- RAM 4GB

- Harddisk 500GB

- Operating System Windows 10

2. Software (Perangkat Lunak)

- Sistem Operasi : Windows 10 Pro 64bit.

- Server database menggunakan MySQL client version: 5.6.12.

- Server web menggunakan WampServer 2.4.

- PHP Version 5.4 .12 sebagai Script Languange.

- phpMyAdmin Version 4.0.4 sebagai Database Manager.

- Browser : Mozilla Firefox.

d. Perancangan Interface

Perancangan interface dibuat dengan tujuan agar mudah dimengerti oleh pemakainya. Perancangan interface meliputi:

1. Perancangan Input

Perancangan input merupakan tampilan yang nantinya akan dibuat untuk menginput data-data dalam sistem.

2. Perancangan output

Perancangan Output digunakan untuk merancang interface output atau keluaran data berupa laporan hasil dari sistem. 
e. Perancangan Database

Perancangan Database digunakan untuk merancang penyimpanan data pada sistem sesuai dengan inputan data.

f. Algoritma C4.5

Algoritma C4.5 sebagai pembentuk pohon keputusan, secara umum algoritma C4.5 untuk membangun pohon keputusan [1] adalah sebagai berikut ;

a. Pilih atribut sebagai akar.

b. Buat cabang untuk tiap-tiap nilai.

c. Bagi kasus dalam cabang.

d. Ulangi proses untuk setiap cabang sampai semua kasus pada cabang memiliki kelas yang sama.

Untuk memilih atribut sebagai akar didasarkan pada nilai gain tertinggi dari atribut-atribut yang ada. Untuk menghitung gain digunakan rumus seperti tertera dalam persamaan 1 berikut.

$\operatorname{Gain}(S, A)=\operatorname{Entropy}(S)-\sum_{i=1}^{n} \frac{\left|S_{i}\right|}{|S|}$
$* \operatorname{Entropy}(S i), \ldots \ldots \ldots$

Keterangan:

$\mathrm{S} \quad$ : Himpunan Kasus

A : Atribut

$\mathrm{n} \quad$ : jumlah partisi atribut $A$

|Si| : jumlah kasus pada partisi ke-i

|S| : Jumlah Kasus dalam S

Sementara itu, perhitungan nilai entropi pada [1] dapat dilihat pada persaman 2 berikut.

$$
\operatorname{Entropy}(S)=\sum_{i=1}^{n}-p i * \log _{2} p i
$$

Keterangan:

$\mathrm{S} \quad$ : Himpunan Kasus

A : Fitur

$\mathrm{n} \quad$ : jumlah partisi S

pi $\quad$ : proporsi dari $S_{i}$ terhadap S.

\subsection{Implementasi}

Implementasi perangkat lunak menggunakan bahasa pemrograman $P H P$ Hypertext Preprocessor (PHP) dengan database manajemen MySql. Sedangkan dalam pembuatan web desainnya menggunakan Adobe Dreamweaver.

3.4. Pengujian Sistem

a. Uji fungsionalitas
Pengujian black box berfokus pada pengujian persyaratan fungsional perangkat lunak, untuk mendapatkan serangkaian kondisi input yang sesuai dengan persyaratan fungsional suatu program.

b. Uji Validitas

Uji validitas adalah pengujian yang digunakan untuk membandingkan antara hasil program yang dibuat memiliki kesamaan dengan hasil identifikasi oleh seorang montir.

\section{HASIL DAN PEMBAHASAN}

4.1 Atribut Akar

Untuk memilih atribut akar didasarkan pada nilai gain tertinggi dari atribut-atribut yang ada.

Tabel 1. Perhitungan Node 1

\begin{tabular}{|c|c|c|c|c|c|c|}
\hline $\begin{array}{l}\text { Node } \\
1\end{array}$ & & $\begin{array}{l}\text { Jml } \\
\text { Kasu } \\
\text { s }\end{array}$ & $\begin{array}{l}\text { Tid } \\
\text { ak }\end{array}$ & $\begin{array}{l}\mathbf{Y} \\
\mathbf{a}\end{array}$ & $\begin{array}{l}\text { Entro } \\
\text { py }\end{array}$ & Gain \\
\hline Total & & 23 & 13 & $\begin{array}{l}1 \\
0\end{array}$ & $\begin{array}{l}0.987 \\
6\end{array}$ & \\
\hline \multicolumn{2}{|c|}{ Saluran Bahan Bakar } & & & & & $\begin{array}{l}0.05 \\
4\end{array}$ \\
\hline & $\begin{array}{l}\text { Tidak Mengalir } \\
\text { Bebas }\end{array}$ & 1 & 0 & 1 & 0 & \\
\hline & Mengalir Bebas & 22 & 13 & 9 & 0.976 & \\
\hline \multicolumn{2}{|l|}{ Busi } & & & & & $\begin{array}{l}0.14 \\
33\end{array}$ \\
\hline & Baik & 20 & 12 & 8 & $\begin{array}{l}0.970 \\
9\end{array}$ & \\
\hline & Basah & 1 & 1 & 0 & 0 & \\
\hline & $\begin{array}{ll}\text { Bunga } & \text { Api } \\
\text { Lemah } & \\
\end{array}$ & 1 & 0 & 1 & 0 & \\
\hline & Tidak Baik & 1 & 0 & 1 & 0 & \\
\hline \multicolumn{2}{|c|}{$\begin{array}{ll}\text { Tekanan } & \text { Kompresi } \\
\text { Cylinder } & \\
\end{array}$} & & & & & $\begin{array}{l}0.03 \\
68 \\
\end{array}$ \\
\hline & Sesuai & 22 & 12 & $\begin{array}{l}1 \\
0\end{array}$ & 0.994 & \\
\hline & Tidak Sesuai & 1 & 1 & 0 & & \\
\hline \multicolumn{3}{|c|}{ Mesin Hidup Tetapi Mati Kembali } & & & & $\begin{array}{l}0.00 \\
25\end{array}$ \\
\hline & $\mathrm{Ya}$ & 19 & 11 & 8 & $\begin{array}{l}0.981 \\
9\end{array}$ & \\
\hline & Tidak & 4 & 2 & 2 & 1 & \\
\hline \multicolumn{2}{|c|}{ Tinggi Permukaan Oli } & & & & & $\begin{array}{l}0.03 \\
68 \\
\end{array}$ \\
\hline \multirow[t]{3}{*}{$\begin{array}{l}\text { Node } \\
1\end{array}$} & & $\begin{array}{l}\text { Juml } \\
\text { ah } \\
\text { Kasu } \\
\text { s }\end{array}$ & $\begin{array}{l}\text { Tida } \\
\mathrm{k}\end{array}$ & $\begin{array}{l} \\
\mathrm{Y} \\
\mathrm{a}\end{array}$ & $\begin{array}{l}\text { Entro } \\
\text { py }\end{array}$ & Gain \\
\hline & Sesuai & 22 & 12 & $\begin{array}{l}1 \\
0\end{array}$ & 0.994 & \\
\hline & Tidak Sesui & 1 & 1 & 0 & 0 & \\
\hline \multicolumn{2}{|c|}{ Kondisi Oli } & & & & & $\begin{array}{l}0.05 \\
4\end{array}$ \\
\hline & Baik & 22 & 13 & 9 & 0.976 & \\
\hline & Tidak Baik & 1 & 0 & 1 & 0 & \\
\hline \multicolumn{2}{|c|}{ Roda Berputar Bebas } & & & & & $\begin{array}{l}0.05 \\
4\end{array}$ \\
\hline & $\mathrm{Ya}$ & 22 & 13 & 9 & 0.976 & \\
\hline & Tidak & 1 & 0 & 1 & 0 & \\
\hline
\end{tabular}




\begin{tabular}{|l|l|l|l|l|l|l|}
\hline $\begin{array}{l}\text { Node } \\
\mathbf{l}\end{array}$ & $\begin{array}{l}\text { Jml } \\
\text { Kasu } \\
\text { s }\end{array}$ & $\begin{array}{l}\text { Tid } \\
\text { ak }\end{array}$ & $\begin{array}{l}\text { Y } \\
\mathbf{a}\end{array}$ & $\begin{array}{l}\text { Entro } \\
\text { py }\end{array}$ & Gain \\
\hline \multicolumn{2}{|l|}{ Tekanan Udara Ban } & & & & & $\begin{array}{l}0.03 \\
68\end{array}$ \\
\hline & Sesuai & 22 & 12 & 1 & 0.994 & \\
& & 1 & 1 & 0 & 0 & \\
\hline & Rendah & 1 & & & \\
\hline
\end{tabular}

Baris total kolom entropy pada Tabel 1 dihitung dengan persamaan 2 sebagai berikut:

Entropy(Total)

$$
\begin{gathered}
=\left(-\frac{13}{23} * \log _{2}\left(\frac{13}{23}\right)\right) \\
+\left(-\frac{10}{23} * \log _{2}\left(\frac{10}{23}\right)\right) \\
\text { Entropy }(\text { Total })=0.9876
\end{gathered}
$$

Sementara itu, nilai gain pada baris saluran bahan bakar dan gain pada baris busi dihitung menggunakan persamaan 1 sebagai berikut :

$$
\text { Gain(Total, Saluran Bahan Bakar) }
$$

$$
\begin{aligned}
& =0.9876 \\
& -\left(\left(\frac{1}{23} * 0\right)+\left(\frac{22}{23} * 0.976\right)\right)
\end{aligned}
$$

gain (Total, Saluran Bahan Bakar $)=0.054$

Gain(Total, Busi)

$$
\begin{aligned}
& \quad=0.9876 \\
& -\left(\left(\frac{20}{22} * 0.9709\right)+\left(\frac{1}{22} * 0\right)\right. \\
& \left.+\left(\frac{1}{22} * 0\right)\right) \\
& \text { gain }(\text { Total, Busi })=0.1433
\end{aligned}
$$

Untuk gain yang lainnya masih menggunakan persamaan 1 dalam perhitungannya, untuk persamaan 2 digunakan untuk menghitung entropy. Berdasarkan Tabel 1 gain tertinggi didapat oleh busi, busi mempunyai empat atribut dimana atribut busi basah, bunga api lemah dan tidak baik telah mengklasifikasikan kasus menjadi satu atau salah satu nilai atribut kosong. Sehingga atribut tersebut tidak perlu dilakukan perhitungan lagi karena sudah didapatkan hasil akhirnya. Sedangkan untuk atribut baik mempunyai nilai atribut tidak 12 dan baik 8, maka masih perlu dilakukan perhitungan lagi. Dari Tabel 1 didapatkan pohon keputusan sementara pada Gambar 1.

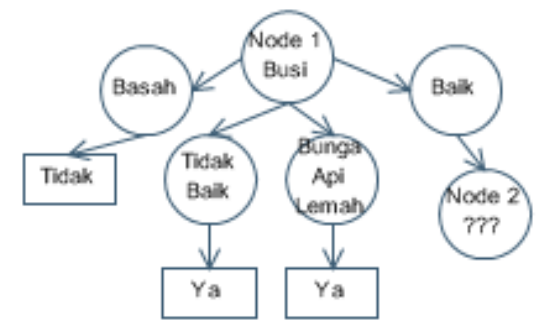

Gambar 1 Pohon Keputusan Node 1

Node selanjutnya dihitung sampai nilai atribut mengklasifikasikan nilai atribut menjadi satu nilai.

\subsection{Aturan Produksi}

Aturan produksi dibuat berdasarkan pohon keputusan yang telah dibuat sebelumnya. Aturan produksi ini menggunakan IF-THEN, IF merupakan informasi masukan, sedangkan THEN merupakan konklusi atau kesimpulan. Bentuk umum dari aturan IF-THEN ini adalah :

\section{IF Periksa A AND Periksa B AND ..... AND Periksa X THEN Kerusakan 1}

Tabel aturan produksi yang dibuat untuk mendiagnosa kerusakan sepeda motor Vario 4 Tak dapat dilihat pada Tabel 2.

\section{Tabel 2. Aturan Produksi}

\begin{tabular}{|l|l|}
\hline No & Aturan \\
\hline 1 & $\begin{array}{l}\text { IF Busi Bunga api lemah THEN Busi tidak } \\
\text { bekerja dengan baik, Busi kotor, Kabel-kabel } \\
\text { sistem pengapian longgar atau terlepas, Kabel } \\
\text { busi putus atau ada hubungan singkat, Koil } \\
\text { pengapian tidak bekerja dengan baik, Ignition } \\
\text { pulse generator tidak bekerja dengan baik, Kunci } \\
\text { kontak tidak bekerja dengan baik, Igniton control } \\
\text { modle (ICM) tidak bekerja dengan baik dan } \\
\text { Kawat side stand switch terputus }\end{array}$ \\
\hline 2 & $\begin{array}{l}\text { IF Busi Tidak baik THEN Busi kurang sering } \\
\text { diservis, Derajat panas busi tidak sesuai dan } \\
\text { Busi tidak bekerja dengan baik }\end{array}$ \\
\hline 3 & $\begin{array}{l}\text { IF Busi Baik AND Kondisi Oli Tidak Baik THEN } \\
\text { Oli Lama tidak diganti }\end{array}$ \\
\hline 4 & $\begin{array}{l}\text { IF Busi Baik AND Kondisi Oli Baik AND Saluran } \\
\text { Bahan Bakar Tidak Mengalir Bebas THEN } \\
\text { Saluran Bahan Bakar Tersumbat, Fuel Auto } \\
\text { Valve Tersumbat, Lubang Pernapasan Fuel } \\
\text { Tank Tersumbat dan Fuel Strainer (Saringan } \\
\text { Bahan Bakar) Tersumbat }\end{array}$ \\
\hline 5 & $\begin{array}{l}\text { IF Busi Baik AND Kondisi Oli Tidak Baik AND } \\
\text { Saluran Bahan Bakar Mengalir Bebas AND } \\
\text { Putaran Stasioner Tidak Benar THEN Setel } \\
\text { Putaran Stasioner pada karburator. }\end{array}$ \\
\hline 6 & $\begin{array}{l}\text { IF Busi Baik AND Kondisi Oli Tidak Baik AND } \\
\text { Saluran Bahan Bakar Mengalir Bebas AND } \\
\text { Putaran Stasioner Benar AND Ada Kebocoran } \\
\text { Intlet Pipe THEN Intlet Pipe Longgar. }\end{array}$ \\
\hline 7 & $\begin{array}{l}\text { IF Busi Baik AND Kondisi Oli Tidak Baik AND } \\
\text { Saluran Bahan Bakar Mengalir Bebas AND }\end{array}$ \\
\hline
\end{tabular}




\begin{tabular}{|c|c|}
\hline No & Aturan \\
\hline & $\begin{array}{l}\text { Putaran Stasioner Benar AND Tidak Ada } \\
\text { Kebocoran Intlet Pipe AND Roda Tidak Berputar } \\
\text { Bebas THEN Rem menyangkut, Bantalan final } \\
\text { reduction dan driven pulley aus atau rusak dan } \\
\text { Final shaft bengkok. }\end{array}$ \\
\hline 8 & $\begin{array}{l}\text { IF Busi Baik AND Kondisi Oli Tidak Baik AND } \\
\text { Saluran Bahan Bakar Mengalir Bebas AND } \\
\text { Putaran Stasioner Benar AND Tidak Ada } \\
\text { Kebocoran Intlet Pipe AND Roda Berputar } \\
\text { Bebas AND Mesin Mengelitik THEN Piston dan } \\
\text { cyllinder aus, Jenis bahan bakar yang salah, Ada } \\
\text { pembentukan karbon berlebihan pada ruang } \\
\text { pembakaran, Waktu pengapian terlalu maju } \\
\text { (ICM tidak bekerja dengan baik) dan Campuran } \\
\text { bahan bakar terlalu miskin. }\end{array}$ \\
\hline No & Aturan \\
\hline 9 & $\begin{array}{l}\text { IF Busi Baik AND Kondisi Oli Tidak Baik AND } \\
\text { Saluran Bahan Bakar Mengalir Bebas AND } \\
\text { Putaran Stasioner Benar AND Tidak Ada } \\
\text { Kebocoran Intlet Pipe AND Roda Berputar } \\
\text { Bebas AND Mesin Tidak Mengelitik AND Mesin } \\
\text { Panas Berlebihan THEN Tinggi permukaan } \\
\text { cairan pendingin terlalu rendah, Thermostat } \\
\text { macet tertutup, } \\
\text { Ada pembentukan karbon berlebihan dalam } \\
\text { ruang pembakaran, Pemakaian bahan bakar } \\
\text { dengan kualitas buruk dan Campuran bahan } \\
\text { bakar terlalu miskin. }\end{array}$ \\
\hline 10 & $\begin{array}{l}\text { IF Busi Baik AND Kondisi Oli Tidak Baik AND } \\
\text { Saluran Bahan Bakar Mengalir Bebas AND } \\
\text { Putaran Stasioner Benar AND Tidak Ada } \\
\text { Kebocoran Intlet Pipe AND Roda Berputar } \\
\text { Bebas AND Mesin Tidak Mengelitik AND Mesin } \\
\text { Tidak Panas Berlebihan AND Kemudi Terlalu } \\
\text { Keras THEN Steering stem adjusting nut terlalu } \\
\text { kencang, Bantalan steering head rusak dan } \\
\text { Tekanan angin ban kurang. }\end{array}$ \\
\hline
\end{tabular}

\subsection{Perancangan dan Implementasi Sistem}

a. Halaman Index Pengguna

Gambar 2 Menunjukkan halaman yang akan ditampilkan saat aplikasi ditampilkan pertama kali dan berisi tentang informasi kendaraan Honda Vario 110cc. Halaman ini merupakan tampilan yang akan ditampilkan kepada pengguna yang akan melakukan konsultasi mengenai kendaraan honda vario 110cc.

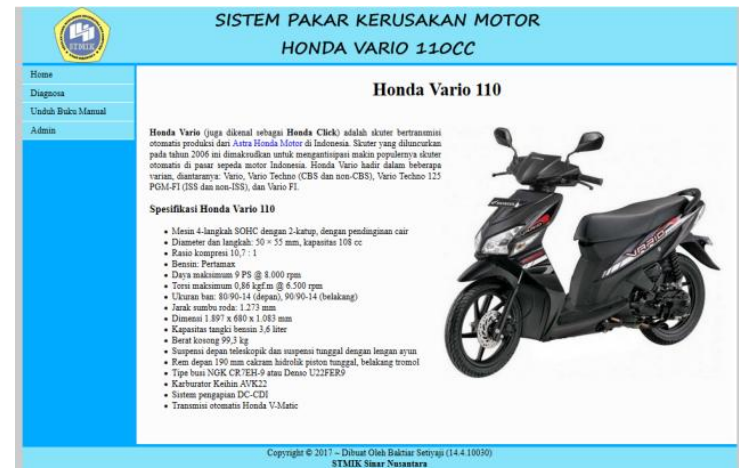

Gambar 2. Halaman Index Pengguna b. Halaman Keterangan Motor

Gambar 3 menunjukkan halaman yang berguna untuk memasukkan data motor seperti nama pemilik kendaraan serta nomor plat kendaraan. Setelah mengisi keseluruhan data maka pengguna menekan tombol lanjut untuk selanjutnya melakukan konsultasi dengan sistem.

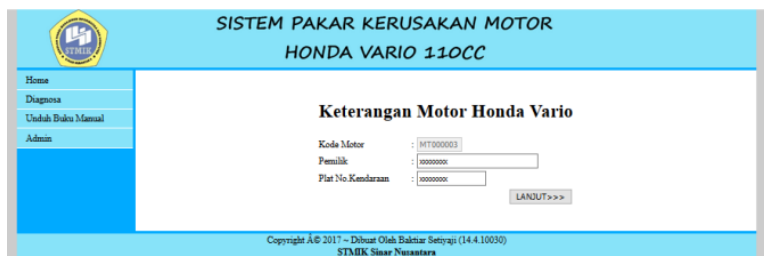

Gambar 3. Halaman Keterangan Motor

c. Halaman Konsultasi

Gambar 4. menunjukkan halaman yang menampilkan pertanyaan yang nantinya akan dijawab oleh pengguna dan akan diolah oleh sistem. Apabila data yang dijawab sudah terpenuhi maka akan ditampilkan hasil dari konsultasi pengguna.

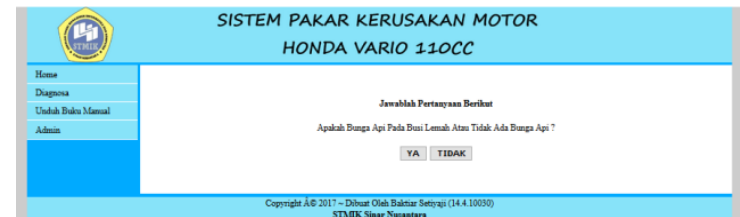

Gambar 4. Halaman Konsultasi

\section{d. Halaman Hasil Pengecekan}

Gambar 5 menunjukkan halaman yang menampilkan data motor yang telah dimasukkan sebelum melakukan konsultasi beserta hasil konsultasi yang telah didapat setelah melakukan konsultasi.

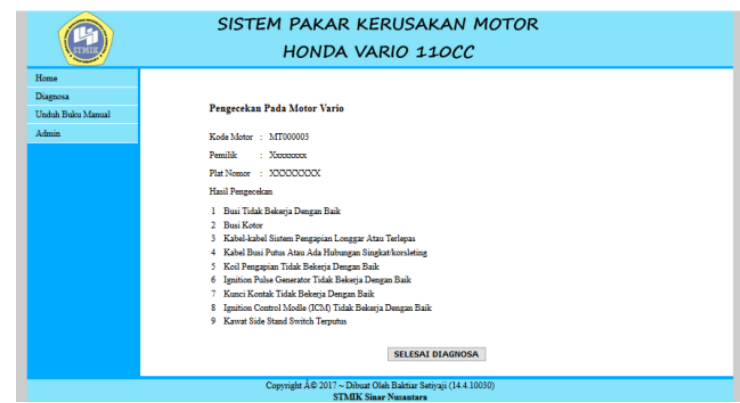

Gambar 5. Halaman Hasil Pengecekan

e. Halaman Index Admin

Gambar 6 menunjukkan halaman yang akan ditampilkan jika admin melakukan login dengan benar. Halaman ini berisi informasi kendaraan serta menu navigasi untuk melakukan perubahan pada sistem. 


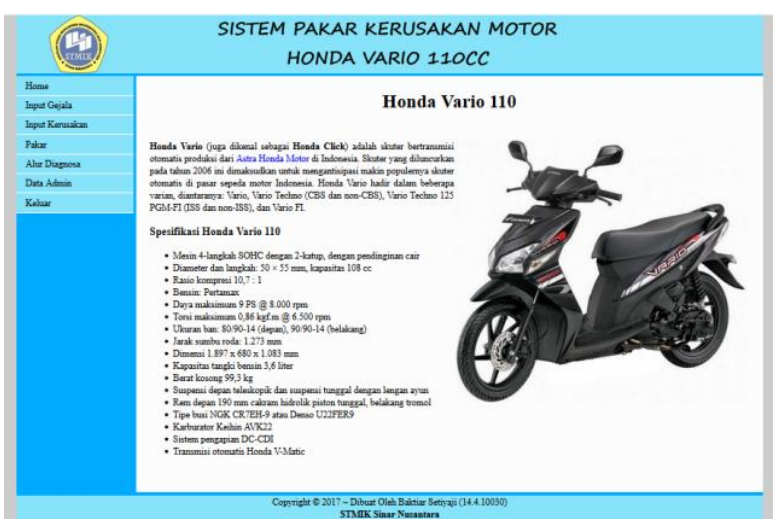

Gambar 6 Halaman Index Admin

\subsection{Pengujian Sistem}

1. Pengujian Fungsionalitas

Pengujian program dilakukan menggunakan pengujian fungsional untuk menguji fungsi-fungsi dari aplikasi yang dikembangkan. Tes input dan output fungsi yang ada tanpa memperhatikan prosesnya.

\section{a. Konsultasi}

Tabel 3. Konsultasi

\begin{tabular}{|c|c|c|c|}
\hline Test case & Hasil harapan & $\begin{array}{l}\text { Hasil } \\
\text { keluaran }\end{array}$ & $\begin{array}{l}\text { Hasil } \\
\text { uji }\end{array}$ \\
\hline $\begin{array}{l}\text { Pengguna } \\
\text { memasukkan } \\
\text { jawaban dari } \\
\text { pertanyaan } \\
\text { yang } \\
\text { ditampilkan } \\
\text { sistem }\end{array}$ & $\begin{array}{l}\text { Menampilkan } \\
\text { pertanyaan } \\
\text { selanjutnya } \\
\text { atau masuk } \\
\text { form hasil } \\
\text { pengecekan }\end{array}$ & $\begin{array}{l}\text { Menampilkan } \\
\text { pertanyaan } \\
\text { selanjutnya } \\
\text { atau masuk } \\
\text { form hasil } \\
\text { pengecekan }\end{array}$ & Sesuai \\
\hline
\end{tabular}

\section{b. Login Admin}

Tabel 4. Login Admin

\begin{tabular}{|c|c|c|c|}
\hline Test case & $\begin{array}{l}\text { Hasil } \\
\text { harapan }\end{array}$ & $\begin{array}{l}\text { Hasil } \\
\text { keluaran }\end{array}$ & Hasil uji \\
\hline $\begin{array}{l}\text { Masukkan } \\
\text { data login } \\
\text { berupa } \\
\text { username } \\
\text { dan } \\
\text { password } \\
\text { yang benar }\end{array}$ & $\begin{array}{l}\text { Cek validasi } \\
\text { username } \\
\text { dan } \\
\text { password } \\
\text { sesuai } \\
\text { database }\end{array}$ & $\begin{array}{l}\text { Masuk } \\
\text { kedalam } \\
\text { form index } \\
\text { admin }\end{array}$ & Sesuai \\
\hline $\begin{array}{l}\text { Masukkan } \\
\text { data login } \\
\text { berupa } \\
\text { username } \\
\text { dan }\end{array}$ & $\begin{array}{l}\text { Penolakan } \\
\text { validasi } \\
\text { username } \\
\text { dan } \\
\text { password } \\
\text { yang }\end{array}$ & $\begin{array}{l}\text { Kembali ke } \\
\text { form login }\end{array}$ & Sesuai \\
\hline Test case & $\begin{array}{l}\text { Hasil } \\
\text { harapan }\end{array}$ & $\begin{array}{l}\text { Hasil } \\
\text { keluaran }\end{array}$ & Hasil uji \\
\hline $\begin{array}{l}\text { password } \\
\text { yang salah }\end{array}$ & $\begin{array}{l}\text { tidak sesuai } \\
\text { dalam } \\
\text { database }\end{array}$ & $\begin{array}{l}\text { Kembali ke } \\
\text { form login }\end{array}$ & $\begin{array}{l}\text { Kembali } \\
\text { ke form } \\
\text { login }\end{array}$ \\
\hline
\end{tabular}

\section{Pengujian Validasi}

Pengujian validasi dilakukan dengan cara membandingkan kinerja sistem dengan data rekam kerusakan motor Vario 110cc karburasi yang didapatkan dari mekanik.
Tabel 5. Data Pengujian

\begin{tabular}{|c|c|c|c|c|}
\hline No & Gejala & $\begin{array}{l}\text { Hasil } \\
\text { pengecekan }\end{array}$ & Hasil Sistem & Hasil \\
\hline 1 & \multirow{4}{*}{$\begin{array}{l}\text { Busi Baik, } \\
\text { Kondisi } \\
\text { Oli Baik, } \\
\text { Saluran } \\
\text { Bahan } \\
\text { Bakar } \\
\text { Tidak } \\
\text { Mengalir } \\
\text { Bebas }\end{array}$} & $\begin{array}{l}\text { Selang } \\
\text { tersumbat }\end{array}$ & \multirow{4}{*}{$\begin{array}{l}\text { - Saluran } \\
\text { Bahan } \\
\text { Bakar } \\
\text { Tersumbat } \\
\text { - Fuel Auto } \\
\text { Valve } \\
\text { Tersumbat. } \\
\text { - Lubang } \\
\text { Pernapasan } \\
\text { Fuel Tank } \\
\text { Tersumbat } \\
\text { - Fuel } \\
\text { Strainer } \\
\text { (Saringan } \\
\text { Bahan } \\
\text { Bakar) } \\
\text { Tersumbat }\end{array}$} & Sesuai \\
\hline 2 & & $\begin{array}{l}\text { Vacum } \\
\text { bensin rusak }\end{array}$ & & Sesuai \\
\hline 3 & & Tangki kotor & & Sesuai \\
\hline 4 & & $\begin{array}{l}\text { Saluran } \\
\text { pernapasa } \\
\text { tangki } \\
\text { tersumbat } \\
\end{array}$ & & Sesuai \\
\hline No & Gejala & $\begin{array}{l}\text { Hasil } \\
\text { pengecekan }\end{array}$ & Hasil Sistem & Hasil \\
\hline 5 & $\begin{array}{l}\text { Bunga api } \\
\text { lemah } \\
\text { atau tidak }\end{array}$ & $\begin{array}{l}\text { Cop busi } \\
\text { rusak }\end{array}$ & $\begin{array}{l}\text { - Busi tidak } \\
\text { bekerja } \\
\text { dengan baik }\end{array}$ & Sesuai \\
\hline 6 & bunga & $\begin{array}{l}\text { Cop busi } \\
\text { longqar }\end{array}$ & & Sesuai \\
\hline 7 & & $\begin{array}{l}\text { Kabel busi } \\
\text { putus }\end{array}$ & & Sesuai \\
\hline 8 & api pada & Koil rusak & - Kabel-kabel & Sesuai \\
\hline 9 & busi & Cdi rusak & sistem & Sesuai \\
\hline 10 & & $\begin{array}{l}\text { Kabel cdi ke } \\
\text { koil putus }\end{array}$ & $\begin{array}{l}\text { pengapian } \\
\text { longgar atau } \\
\text { terlepas } \\
\text { - Kabel busi } \\
\text { putus atau } \\
\text { ada } \\
\text { hubungan } \\
\text { singkat } \\
\text { - Koil } \\
\text { pengapian } \\
\text { tidak } \\
\text { bekerja } \\
\text { dengan baik } \\
\text { - Ignition } \\
\text { pulse } \\
\text { generator } \\
\text { tidak } \\
\text { bekerja } \\
\text { dengan baik } \\
\text { - Kunci } \\
\text { kontak tidak } \\
\text { bekerja } \\
\text { dengan baik } \\
\text { - Igniton } \\
\text { control } \\
\text { modle (ICM) } \\
\text { tidak } \\
\text { bekerja } \\
\text { dengan baik } \\
\text { - Kawat side } \\
\text { stand switch } \\
\text { terputus } \\
\end{array}$ & Sesuai \\
\hline 11 & $\begin{array}{l}\text { Busi Baik, } \\
\text { Kondisi oli }\end{array}$ & $\begin{array}{l}\text { Ring seher } \\
\text { aus }\end{array}$ & $\begin{array}{l}\text { - Oli lama } \\
\text { tidak diganti }\end{array}$ & $\begin{array}{l}\text { Tidak } \\
\text { Sesuai }\end{array}$ \\
\hline 12 & tidak baik & $\begin{array}{l}\text { Oli lama } \\
\text { tidak diganti }\end{array}$ & & Sesuai \\
\hline 13 & Busi Baik, & Bearing & - Rem & Sesuai \\
\hline
\end{tabular}




\begin{tabular}{|c|c|c|c|c|}
\hline No & Gejala & $\begin{array}{l}\text { Hasil } \\
\text { pengecekan }\end{array}$ & Hasil Sistem & Hasil \\
\hline & \multirow{2}{*}{$\begin{array}{l}\text { Kondisi } \\
\text { Oli Tidak, }\end{array}$} & rusak & \multirow{2}{*}{$\begin{array}{l}\text { menyangkut } \\
\text { - Bantalan } \\
\text { final }\end{array}$} & \\
\hline 14 & & $\begin{array}{l}\text { Rem } \\
\text { menyangkut }\end{array}$ & & Sesuai \\
\hline No & Gejala & $\begin{array}{l}\text { Hasil } \\
\text { pengecekan }\end{array}$ & Hasil Sistem & Hasil \\
\hline 15 & $\begin{array}{l}\text { Baik, } \\
\text { Saluran } \\
\text { Bahan } \\
\text { Bakar } \\
\text { Mengalir } \\
\text { Bebas } \\
\text { Putaran } \\
\text { Stasioner } \\
\text { Benar, } \\
\text { Tidak Ada } \\
\text { Kebocora } \\
\text { n Intlet } \\
\text { Pipe, } \\
\text { Roda } \\
\text { Tidak } \\
\text { Berputar } \\
\text { Bebas }\end{array}$ & $\begin{array}{l}\text { Cakram } \\
\text { bengkok }\end{array}$ & $\begin{array}{l}\text { reduction } \\
\text { dan driven } \\
\text { pulley aus } \\
\text { atau rusak } \\
\text { - Final shaft } \\
\text { bengkok }\end{array}$ & $\begin{array}{l}\text { Tidak } \\
\text { Sesuai }\end{array}$ \\
\hline
\end{tabular}

Hasil pengecekan pada tabel diatas akan dilakukan pengujian akurasi data kerusakan dan gejala dari kerusakan Honda Vario 110CC karburasi menggunakan metode Confusion Matrix. Kemudian dapat dihitung akurasi dari sistem tersebut sebagai berikut :

$$
\begin{aligned}
& \text { Nilai akurasi } \\
& =\frac{\text { Jumlah data akurat }}{\text { Jumlah seluruh data }} \times 100 \% \\
& =\frac{13}{15} \times 100 \% \\
& =86.7 \%
\end{aligned}
$$

Prosentase yang didapatkan dari hasil pengecekan kerusakan dengan sistem sebesar $86.7 \%$.

\section{PENUTUP}

\subsection{Kesimpulan}

Berdasarkan hasil penelitian serta analisis data yang dilakukan, dapat disimpulkan bahwa sistem pakar diagnosa kerusakan motor 4 tak Honda Vario dengan algoritma C4.5 telah berhasil dibuat dalam bentuk aplikasi berbasis web. Dari data pengujian didapatkan akurasi sebesar $86.7 \%$. Dalam penelitian ini algoritma C4.5 berguna untuk pembuatan pohon keputusan dan rule, dimana rule yang terbentuk dari pohon keputusan berguna untuk menentukan gejala yang paling berpengaruh kepada motor dari beberapa gejala yang ada.

\subsection{Saran}

Berdasarkan hasil dari penelitian yang telah dilakukan maka dapat dikemukakan saran kedepan sebagai berikut : banyaknya hasil kerusakan yang tidak sesuai antara sistem dengan data kerusakan yang didapatkan dari mekanik dengan gejala yang sama maka perlu adanya penambahan akuisisi pengetahuan untuk meningkatkan akurasi diagnosa terhadap kendaraan yang akan dilakukan pengecekan terhadap kerusakan yang terjadi pada kendaraan.

\section{DAFTAR PUSTAKA}

[1] Kusrini and E. T. Lutfhi, Algoritma Data Mining. Yogyakarta: Andi Offset, 2009.

[2] Supyani, "Aplikasi Diagnosa Kerusakan Mesin Sepeda Motor Bebek 4 Tak Dengan Metode Forward Chaining," STMIK Sinar Nusantara, 2012.

[3] S. Kosasi, "Pembuatan Aplikasi Diagnosa Kerusakan Mesin Sepeda Motor Matic dengan Case-Based Reasoning," Citec J., vol. 2, no. 3, pp. 192-206, 2015.

[4] I. Wicaksono, F. N. Hakim, and V. G. Utomo, "Sistem Pakar Diagnosa Kerusakan Pada Motor Matic Vario Berbasis Web ( Studi Kasus: Bengkel Jozz Motor Cangkiran )," J. Transform., vol. 13, no. 2, pp. 49-58, 2016.

[5] C. Jamhari, A. Kiryanto, and S. H. Anwariningsih, "Sistem Pakar Diagnosis Kerusakan Sepeda Motor Non Matic," in Seminar Nasional IENACO-2014, 2014.

[6] A. Rukmana and I. U. Wardati, "Sistem Pakar Untuk Mendiagnosis Kerusakan Sepeda Motor Non Injeksi Pada Bengkel Gemilang Jaya Motor Kabupaten Pacitan," J. Speed - Sentra Penelit. Eng. dan Edukasi, vol. 6, no. 4, pp. 27-30, 2014.

[7] L. Rahmannor and B. Rahmani, "Aplikasi Sistem Pakar Untuk Mendiagnosa Kerusakan Sepeda Motor Suzuki 4 TAK," Progresif, vol. 7, no. 2, pp. 755-770, 2011.

[8] D. Destiani and A. H. A, "Pengembangan Sistem Pakar Diagnosis Kerusakan Sepeda Motor Automatic Non Injeksi Berbasis Android," J. Algoritm., vol. 12, no. 1, pp. 1-7, 2015.

[9] A. S. Aribowo and S. Khomsah, "Sistem Pakar Dengan Beberapa Knowledge Base Menggunakan Probabilitas Bayes Dan Mesin Inferensi Forward Chaining," in Seminar Nasional Informatika, 2011, 
vol. 1 , no. 4 , pp. 51-58.

[10] S. Kurniawan and N. Merlina, "Sistem Pakar Berbasis Web Dengan Menggunakan Metode Forward Chaining Untuk Mendiagnosa Kerusakan Mobil Daihatsu Ayla," J. Pilar Nusa Mandiri, vol. 11, no. 2, pp. 197202, 2015.

[11] T. Sutojo and E. Mulyanto, Kecerdasan Buatan. Yogyakarta: C.V Andi Offset, 2015. 